\title{
Conjugated polymers with benzothiadiazole and benzotriazole moieties for polymer solar cells
}

\author{
Duygu Keles a, Mert Can Erer ${ }^{\mathrm{b}}$, Eda Bolayir ${ }^{\mathrm{b}}$, Sevki Can Cevher ${ }^{\mathrm{b}}$, Gonul Hizalan ${ }^{\mathrm{c}}$, \\ Levent Toppare $^{\text {a, b, c, d }}$, Ali Cirpan ${ }^{\text {a, b, c, e, * }}$ \\ a Department of Polymer Science and Technology, Middle East Technical University, Ankara 06800, Turkey \\ ${ }^{\mathrm{b}}$ Department of Chemistry, Middle East Technical University, Ankara 06800, Turkey \\ ${ }^{\mathrm{c}}$ The Center for Solar Energy Research and Application (GUNAM), Middle East Technical University, Ankara 06800, Turkey \\ d Department of Biotechnology, Middle East Technical University, Ankara 06800, Turkey \\ e Department of Micro and Nanotechnology, Middle East Technical University, Ankara 06800, Turkey
}

\section{A R T I C L E I N F O}

Article history:

Received 31 October 2018

Received in revised form

17 January 2019

Accepted 5 March 2019

Available online 6 March 2019

\section{Keywords:}

Organic solar cells

Conjugated polymers

Benzodithiophene

Benzothiadiazole and benzotriazole

\begin{abstract}
A B S T R A C T
In this study four novel random polymers, comprising benzothiadiazole and benzotriazole as the accepting units and benzodithiophene as the donor unit, were synthesized via Stille polymerization reaction. Moreover, effects of fluorine atom and $\pi$ bridges on optical, electrochemical and optoelectronic properties were investigated. Optical band gap values of P1, P2, P3 and P4 were found as $1.78 \mathrm{eV}, 1.72 \mathrm{eV}$, $1.63 \mathrm{eV}$ and $1.73 \mathrm{eV}$, respectively. Characterization of polymers via UV-Vis-NIR spectroscopy, cyclic voltammetry (CV), gel permeation chromatography (GPC) and thermal analysis were carried out. Polymer solar cells (PSCs) were constructed and characterized in $\mathrm{N}_{2}$ filled glove box. While the polymers act as electron donors, $\mathrm{PC}_{71} \mathrm{BM}$ was the electron acceptor in the PSCs with the device structure of ITO/ PEDOT:PSS/Polymer:PC 71 BM/LiF/Al. As a consequence of measurements under standard AM $1.5 \mathrm{G}$ illumination $\left(100 \mathrm{~mW} / \mathrm{cm}^{2}\right)$, the highest power conversion efficiency values were recorded as $4.10 \% 3.84 \%$, $1.60 \%$ and $3.83 \%$ for P1, P2, P3 and P4 based PSCs, respectively.
\end{abstract}

๑) 2019 Elsevier Ltd. All rights reserved.

\section{Introduction}

Energy production has become a very critical problem due to increasing human population and decreasing fossil fuel resources around the world. Search for reliable, cheap and environmentally friendly energy sources revealed renewable energy sources [1]. Among them, solar energy takes attention since it is available in almost everywhere on the earth. Due to their low cost, simple fabrication to large scale, solution processability, flexibility and low weight, polymer solar cells (PSCs) aroused interest [2,3]. Power conversion efficiency (PCE) values over 17\% have been achieved recently via tandem cell architecture [4]. The enhancement of the PCE value can be achieved by design of narrower band gap and high mobility polymers and device processing treatments, which provide morphology control at the nanoscale. These treatments include the treatment of the active layer by solvent [5], thermal

\footnotetext{
* Corresponding author. Department of Polymer Science and Technology, Middle East Technical University, Ankara 06800, Turkey.

E-mail address: acirpan@metu.edu.tr (A. Cirpan).
}

annealing [6], addition of processing additives [7] for more interpenetrated network between donor and acceptor. With the use of several synthetic methods, HOMO and LUMO levels of the polymers can be tuned to obtain a lower band gap. This provides absorption at the near-IR region that mainly covers the solar spectrum [8,9]. Device performances of PSCs are also affected from selection of donor and acceptor components. Benzothiadiazole (BT) is one of the strongest acceptor moieties and widely used in polymer backbone to construct PSCs $[5,10]$. On the other hand, benzotriazole (BTz) is a weaker acceptor compared to BT since it contains more electron rich "N" atom. Its main advantage on BT is incorporation of an alkyl chain, which provides solubility. These units were used in the same polymer backbone to combine their advantages [11-13]. Introduction of fluorine atom to the polymer backbone is an emerging method to tune the frontier orbital energy levels. Fluorine atom is the most electronegative element and the smallest electron withdrawing group. Therefore, replacing $\mathrm{H}$ atom with $\mathrm{F}$ atom does not cause steric hindrance due to its small size, while it leads to downshifted HOMO and LUMO levels and enhanced $V_{\mathrm{OC}}$ value [14-16]. Stuart et al. also showed that fluorination improves short circuit current $\left(J_{\text {sc }}\right)$ and fill factor $(\mathrm{FF})$ values due to reduced 
charge recombination [17]. Another modification is incorporation of selenophene and thiophene as the $\pi$-bridge segments. Selenophene containing polymers show lower band gap compared to thiophene containing polymer due to more rigid backbone, less aromatic and more quinoid character of selenophene $[18,19]$. Moreover, high polarizable nature of selenophene results in higher charge mobility [20,21].

The main aim of this study is to synthesize novel polymers with broad absorption and suitable band gap for PSC applications. Nonfluorinated and fluorinated benzothiadiazole containing polymers were compared in order to investigate the effect of fluorination on HOMO and LUMO energy levels, open circuit voltage $\left(\mathrm{V}_{\mathrm{oc}}\right)$ and PCE values. Also, effects of selenophene and thiophene bridges on fluorinated polymers were discussed.

\section{Materials and equipments}

All chemicals and solvents were purchased from Sigma Aldrich Chemical Co. Ltd. Triethylamine, toluene and THF were distilled under nitrogen atmosphere before use. For purification step with column chromatography, Merck Silica Gel 60 was used. To verify structure of monomers, nuclear magnetic resonance (NMR) spectra were investigated on a Bruker Spectrospin Avance DPX-400 Spectrometer with internal reference as trimethylsilane (TMS) in deuterated chloroform $\left(\mathrm{CDCl}_{3}\right)$. Polymer films were prepared by coating polymer solutions ( $2 \mathrm{mg} / 1 \mathrm{~mL}$ ) onto the ITO coated glass substrates. Chloroform was used as the solvent in electrochemistry, spectroelectrochemistry and kinetic experiments. Polymer coated ITO (working electrode), Pt wire (counter electrode), and Ag wire (reference electrode) were placed in a cell containing $0.1 \mathrm{M}$ tetrabutylammonium hexafluorophosphate/acetonitrile ( $\mathrm{TBAPF}_{6} / \mathrm{ACN}$ ) mixture. Electrochemical studies were performed with Gamry 600 potentiostat, and an Agilent 8453 spectrometer was used for spectroelectrochemical measurements. PSC device fabrication and characterization were achieved in a glove box system (MBraun). A Perkin Elmer Differential Scanning Calorimetry was used for Differential Scanning Calorimetry (DSC), and a Perkin Elmer Pyris 1 TGA was used for thermal gravimetry analyses (TGA) at a heating rate of $10^{\circ} \mathrm{C} / \mathrm{min}$ under nitrogen atmosphere.

\subsection{Synthesis}

Synthetic pathways of monomers (Scheme 1) and polymers (Scheme 2) were given below. The monomers 4,7-dibromo-2,1,3benzothiadiazole $(2){ }^{1} \mathrm{H}$ NMR $\left(400 \mathrm{MHz}, \mathrm{CDCl}_{3}\right) \delta 7.72(\mathrm{~s}, 2 \mathrm{H}) .{ }^{13} \mathrm{C}$ NMR $\left(101 \mathrm{MHz}, \mathrm{CDCl}_{3}\right) \delta 152.95,132.33,113.91,4,7$-dibromo-2-(2octyldodecyl)-benzotriazole (5) ${ }^{1} \mathrm{H}$ NMR $\left(400 \mathrm{MHz}, \mathrm{CDCl}_{3}\right) \delta 7.38$ $(\mathrm{s}, 2 \mathrm{H}), 4.65(\mathrm{~d}, J=7.2 \mathrm{~Hz}, 2 \mathrm{H}), 2.35-2.26(\mathrm{~m}, 1 \mathrm{H}), 1.32-1.13(\mathrm{~m}$, $32 \mathrm{H}), 0.89-0.79(\mathrm{~m}, 6 \mathrm{H}) .{ }^{13} \mathrm{C}$ NMR $\left(101 \mathrm{MHz}, \mathrm{CDCl}_{3}\right) \delta 143.65$, 129.43, 110.00, 61.16, 39.02, 31.91, 31.86, 31.16, 29.77, 29.60, 29.58, $29.46,29.42,29.33,29.24,26.02,22.68,22.66,14.12,4,7$-bis(5bromothiophen-2-yl)-2-(2-octyldodecyl)-2H-benzo[d] [1-3] triazole (10) ${ }^{1} \mathrm{H}$ NMR $\left(400 \mathrm{MHz}, \mathrm{CDCl}_{3}\right) \delta 7.78(\mathrm{~d}, J=3.8 \mathrm{~Hz}, 2 \mathrm{H})$, $7.50(\mathrm{~s}, 2 \mathrm{H}), 7.11(\mathrm{~d}, J=3.8 \mathrm{~Hz}, 2 \mathrm{H}), 4.72(\mathrm{~d}, J=6.5 \mathrm{~Hz}, 2 \mathrm{H})$, $2.36-2.22(\mathrm{~m}, 1 \mathrm{H}), 1.38-1.30(\mathrm{~m}, 6 \mathrm{H}), 1.27-1.22(\mathrm{~m}, 26 \mathrm{H})$, 0.90-0.84 (m, 6H). ${ }^{13} \mathrm{C}$ NMR $\left(101 \mathrm{MHz}, \mathrm{CDCl}_{3}\right) \delta 141.59,141.30$, $130.84,126.85,122.95,122.04,113.19,39.13,31.95,31.91,31.48$, $29.92,29.68,29.67,29.60,29.37,29.35,26.28,22.71,14.15,4,7-$ bis(5-bromoselenophen-2-yl)-2-(2-octyldodecyl)-2H-benzo[d] [13]triazole (11) ${ }^{1} \mathrm{H}$ NMR $\left(400 \mathrm{MHz}, \mathrm{CDCl}_{3}\right) \delta 7.76(\mathrm{~d}, J=4.1 \mathrm{~Hz}, 2 \mathrm{H})$, $7.50(\mathrm{~s}, 2 \mathrm{H}), 7.32(\mathrm{~d}, J=4.1 \mathrm{~Hz}, 2 \mathrm{H}), 4.71(\mathrm{~d}, J=6.0 \mathrm{~Hz}, 2 \mathrm{H})$, $2.31-2.21(\mathrm{~m}, J=5.7 \mathrm{~Hz}, 1 \mathrm{H}), 1.47-1.39(\mathrm{~m}, 6 \mathrm{H}), 1.32-1.21(\mathrm{~m}, 26 \mathrm{H})$, $0.92-0.85(\mathrm{~m}, 6 \mathrm{H}){ }^{13} \mathrm{C}$ NMR $\left(101 \mathrm{MHz}, \mathrm{CDCl}_{3}\right) \delta 146.42,141.51$, $133.56,127.03,124.95,121.58,117.76,31.94,31.50,29.94,29.70$, $29.68,29.31,26.37,22.76,14.16,14.11$ and 4,7-dibromo-5-fluoro- 2,1,3-benzothiadiazole (13) ${ }^{1} \mathrm{H}$ NMR (400 MHz, $\left.\mathrm{CDCl}_{3}\right) \delta 7.78$ (d, $J=8.3 \mathrm{~Hz}, 1 \mathrm{H}) .{ }^{13} \mathrm{C}$ NMR $\left(101 \mathrm{MHz}, \mathrm{CDCl}_{3}\right) \delta 158.94,156.40,150.35$, $150.28,147.87,121.59,121.27,111.60,111.49,95.88$, 95.64 were synthesized according to literature [22,23].

\subsubsection{Synthesis of $\mathbf{P 1}$}

(4,8-Bis((2-ethylhexyl)oxy)benzo[1,2-b:4,5- $\left.b^{\prime}\right]$ dithiophene-2,6diyl)bis(trimethylstannane) $(250 \mathrm{mg}, 0.324 \mathrm{mmol}), 4,7$-dibromo2,1,3-benzothiadiazole (47 mg, 0.162), 4,7-dibromo-2-(2octyldodecyl)-benzotriazole ( $90 \mathrm{mg}, 0.162 \mathrm{mmol}$ ) were placed in two-necked round bottom flask and dissolved in $10 \mathrm{~mL}$ toluene under nitrogen atmosphere. Reaction mixture was deoxygenated by bubbling with nitrogen for $45 \mathrm{~min}$. Then, tris(dibenzylideneacetone)dipalladium $\left(7.4 \mathrm{mg}, 8.09 \times 10^{-3} \mathrm{mmol}\right)$ and tri(o-tolyl) phosphine (19 $\mathrm{mg}, 6.47 \times 10^{-2} \mathrm{mmol}$ ) were added and the reaction mixture was stirred at $110^{\circ} \mathrm{C}$ for $40 \mathrm{~h} 2$-(Tributylstannyl)thiophene and 2-bromothiophene were used as the end-capping agents. After removal of toluene under reduced pressure, the polymer was precipitated into methanol. The precipitate was extracted in a Soxhlet apparatus with acetone, hexane and chloroform. The polymer which recovered by chloroform was precipitated into methanol and obtained as blue solid (222 mg, yield: 96\%). Mn: 53 kDa, Mw: 124 kDa.

\subsubsection{Synthesis of $\mathbf{P 2}$}

The same procedure was performed for P2 using (4,8-bis((2ethylhexyl)oxy)benzo[1,2-b:4,5-b']dithiophene-2,6-diyl)bis(trimethylstannane $\quad(277 \mathrm{mg}, \quad 0.359 \mathrm{mmol}), \quad 4,7$-dibromo-2,1,3benzothiadiazole (56 mg, $0.179 \mathrm{mmol}), \quad 4,7$-dibromo-2-(2octyldodecyl)-benzotriazole ( $100 \mathrm{mg}, 0.179 \mathrm{mmol}$ ). A blue polymer was obtained as 197 mg. Yield: 76\%. Mn: 43 kDa, Mw: 112 kDa.

\subsubsection{Synthesis of $\mathbf{P} \mathbf{3}$}

The same procedure was performed for P3 using (4,8-bis((2ethylhexyl)oxy)benzo[1,2-b:4,5-b']dithiophene-2,6-diyl)bis(trimethylstannane) (189 mg, $0.245 \mathrm{mmol}), \quad 4,7$-dibromo-2,1,3benzothiadiazole (38.3 mg, $0.123 \mathrm{mmol}), \quad 4,7-b i s(5-$ bromoselenophen-2-yl)-2-(2-octyldodecyl)-2H-benzo[d] [1-3] triazole (100 $\mathrm{mg}, 0.123 \mathrm{mmol}$ ). A purple polymer was obtained as 205 mg. Yield: 97\%. Mn: 8 kDa Mw: 9 kDa.

\subsubsection{Synthesis of $\mathbf{P 4}$}

The same procedure was performed for P4 using (4,8-bis((2ethylhexyl)oxy)benzo[1,2- $\left.b: 4,5-b^{\prime}\right]$ dithiophene-2,6-diyl)bis(trimethylstannane $) \quad(214 \mathrm{mg}, \quad 0.277 \mathrm{mmol}), \quad 4,7$-dibromo-2,1,3benzothiadiazole (43.2 $\mathrm{mg}, \quad 0.139 \mathrm{mmol}), \quad 4,7-\mathrm{bis}(5-$ bromothiophen-2-yl)-2-(2-octyldodecyl)-2H-benzo[d] [1-3] triazole (100 mg, $0.139 \mathrm{mmol}$ ). A purple polymer was obtained as 213 mg. Yield: 95\%. Mn: 7 kDa, Mw: 15 kDa.

\subsection{Device fabrication}

Photovoltaic parameters of P1, P2, P3 and P4 are investigated with the device structure of ITO/PEDOT:PSS $(40 \mathrm{~nm}) /$ Polymer: $\mathrm{PC}_{71} \mathrm{BM} / \mathrm{LiF}(0.6 \mathrm{~nm}) / \mathrm{Al}(10 \mathrm{~nm})$. ITO glass substrates purchased from Visiontek were cleaned with toluene, detergent, water and isopropyl alcohol respectively in ultrasonic bath. The sonication was carried out for $15 \mathrm{~min}$ for each solvent indicated. Thereafter, substrates were dried with nitrogen gun and $\mathrm{O}_{2}$ plasma treatment was performed for $5 \mathrm{~min}$. This was followed by spincoating of PEDOT:PSS, and baking of the coated substrates at $135^{\circ} \mathrm{C}$ for $15 \mathrm{~min}$. Polymer: $\mathrm{PC}_{71} \mathrm{BM}$ blends with different weight ratios were prepared in $o$-dichlorobenzene $(o-\mathrm{dcb})$. Active layers were spin coated in nitrogen filled glove box. Optimum spincoating rates for P1, P2 and $\mathbf{P 3}$ based blends were determined as 


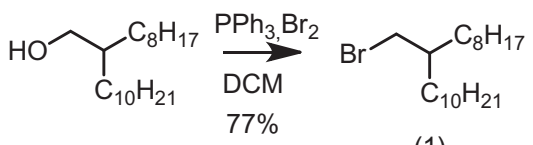

(1)

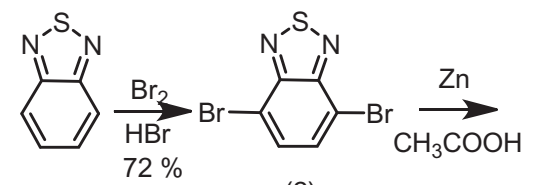

(2)

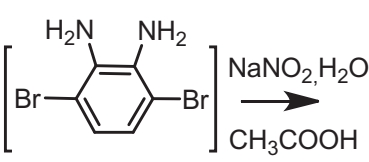

(3)<smiles>Brc1ccc(Br)c2[nH]nnc12</smiles>

(4)

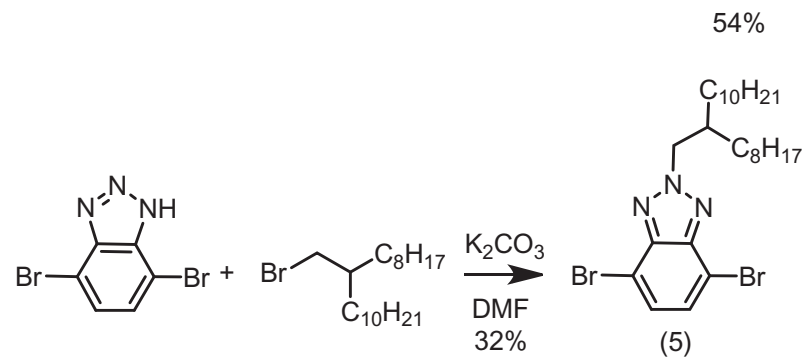

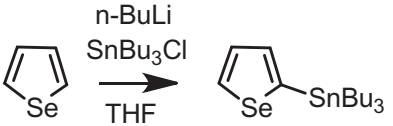

(6)<smiles>CCCC[SbH2]C(C)(C)C(F)(F)c1cccs1</smiles>

(7)

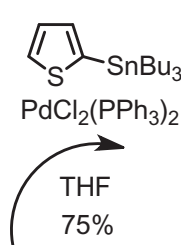

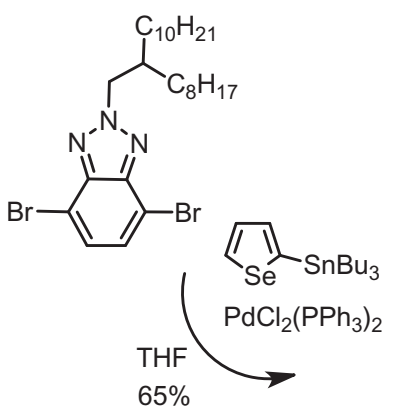
$65 \%$

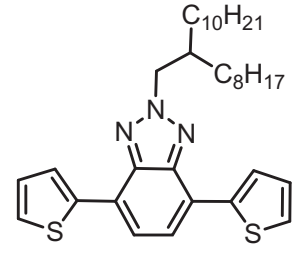

(8)<smiles>CC(C)(C)[Mg][Mg]</smiles>

$69 \%$

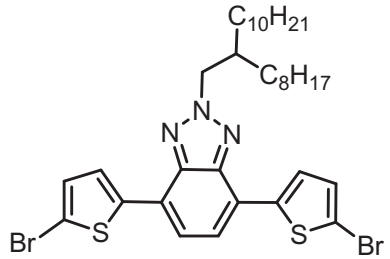

(10)

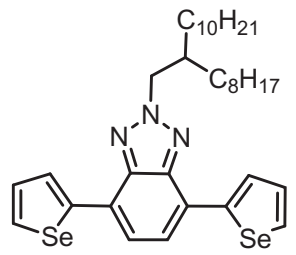

(9)

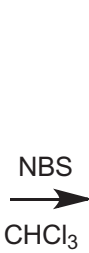

$56 \%$

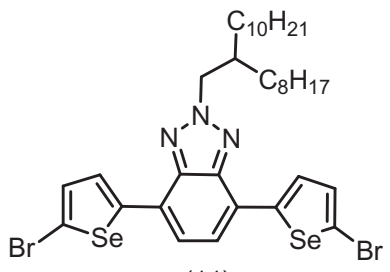

(11)

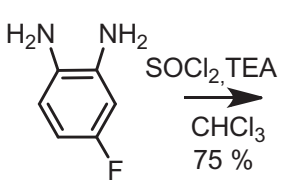

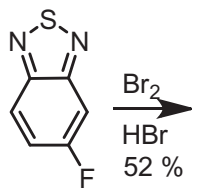

(12)<smiles>Fc1cc(Br)c2nsnc2c1Br</smiles>

(13)

Scheme 1. Synthetic pathways for monomers.

750 rpm, whereas for $\mathbf{P 4}$ based blend it was $1000 \mathrm{rpm}$. $0.6 \mathrm{~nm} \mathrm{LiF}$ and $100 \mathrm{~nm}$ Al layers were deposited on the Polymer:PC ${ }_{71} \mathrm{BM}$ layer at $2 \times 10^{-6}$ mbar, inside the glove box. Photovoltaic measurements of the devices were performed inside the glove box under the illumination of AM 1.5G. The measurements were done by Keithley 2400. Morphologies of active layers were examined via transmission electron microscopy (TEM).

\section{Results and discussions}

\subsection{Electrochemical studies}

In order to investigate the electronic properties cyclic voltammetry experiments were conducted. In electrochemistry experiments, a three electrode experimental setup was established, in 


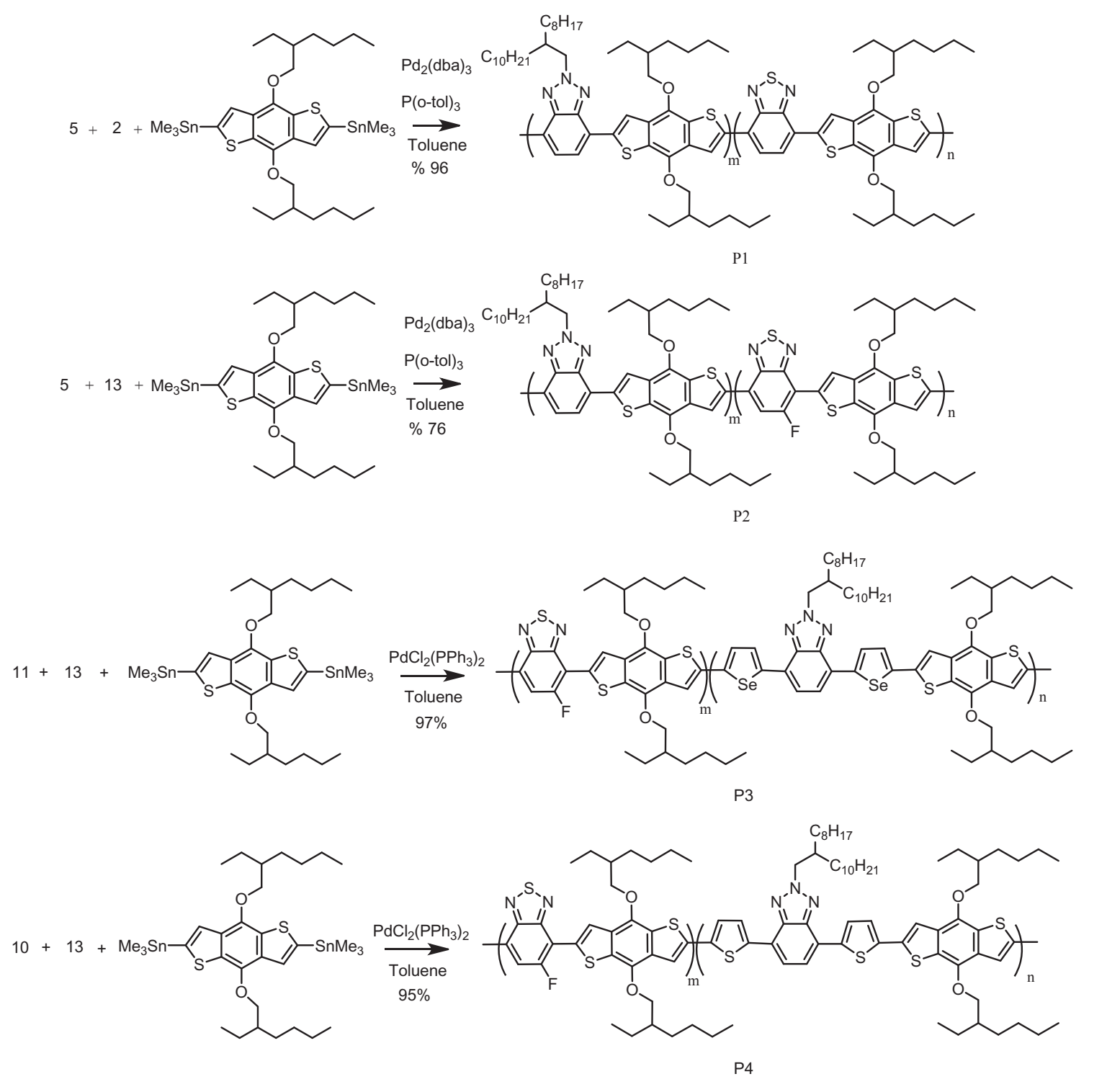

Scheme 2. Synthetic pathways for polymers.

which ITO was used as the working electrode, Ag as the reference electrode and $\mathrm{Pt}$ as the counter electrode. Tetrabutylammonium hexafluorophosphate $\left(\mathrm{TBAPF}_{6}\right)$ was used as the supporting electrolyte, whereas acetonitrile (ACN) was used as the solvent. Cyclic voltammograms were monitored between suitable potentials for P1, P2, P3 and P4 at a scan rate of $100 \mathrm{mV} / \mathrm{s}$ at room temperature. As depicted in Fig. 1 whereas $\mathbf{P 1}$ and $\mathbf{P 2}$ are only p dopable, $\mathbf{P 3}$ and P4 showed ambipolar character. The incorporation of thiophene and selenophene $\pi$ bridges to the polymer backbone, which improve the ion diffusion and ease the dopant ion insertion, may render $\mathrm{n}$ doping process possible.

$\mathrm{P}$ doping redox couples were recorded as $0.98 \mathrm{~V} / 0.63 \mathrm{~V}$ and 1.07 V/0.85 V for P1 and P2, respectively. The difference between oxidation potential of the polymers can be attributed to electron withdrawing nature of the fluorine atom. Electron density of P2 is lower due to fluorinated benzothiadiazole in the polymer backbone. Thus, doping/dedoping processes occur at a higher oxidation potential. On the other hand, redox couples of P3 and P4 are at 1.05/ $0.87 \mathrm{~V}$ and $1.18 / 0.93 \mathrm{~V}$ during p-type doping and at $-1.90 /-1.55 \mathrm{~V}$ and $-1.98 /-1.68 \mathrm{~V}$ during $\mathrm{n}$-type doping, respectively. Stronger electron donating ability of selenophene increases the electron density on the main chain resulting in lower oxidation potential.

HOMO and LUMO energy levels were calculated from oxidation and reduction the onset potentials according to following equations (SHE vs vacuum level was taken as $4.75 \mathrm{eV}$ );

HOMO $=-\left(4.75+E_{\text {ox }}\right.$ onset $)$

$L U M O=-\left(4.75+E_{\text {red }}\right.$ onset $)$

Since P1 and P2 showed only p-dopable character, only HOMO energy levels of the polymers could be calculated from the cyclic voltammetry studies as $-5.45 \mathrm{eV}$ and $-5.55 \mathrm{eV}$ for P1 and P2, respectively. Results were compatible with the fluorine substituents' lowering effect on the HOMO and LUMO energy levels [24,25]. LUMO energy levels of P1 and P2 were estimated by using the optical band gap which was calculated from absorption spectra. According to the formula of $\mathrm{E}_{\mathrm{g}}=\mathrm{E}_{\mathrm{HOMO}}-\mathrm{E}_{\mathrm{LUMO}}$, LUMO levels were calculated as $-3.67 \mathrm{eV}$ for $\mathbf{P 1}$ and $-3.83 \mathrm{eV}$ for P2. Owing to ambipolar features of $\mathbf{P 3}$ and $\mathbf{P 4}$, both HOMO and LUMO energy levels 
a)

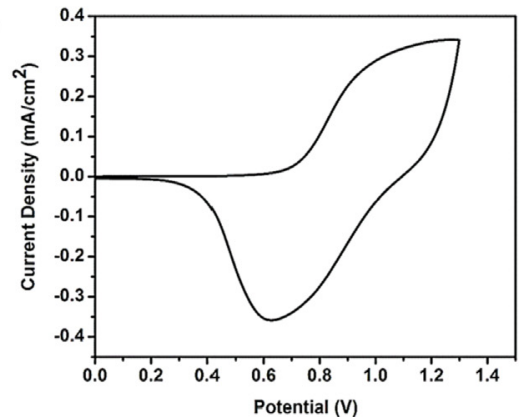

c)

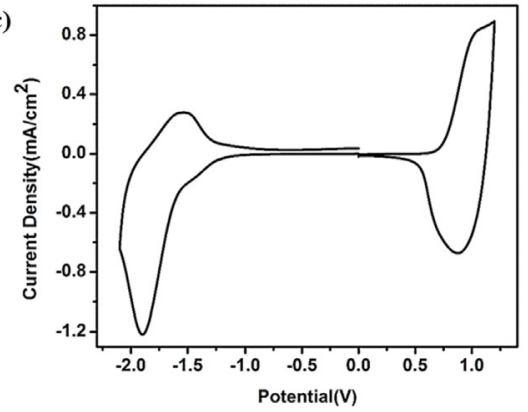

b)

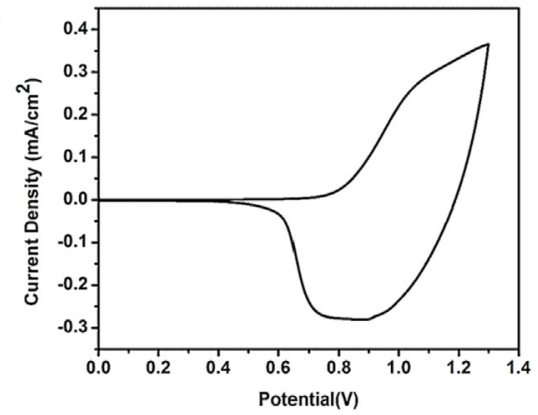

d)

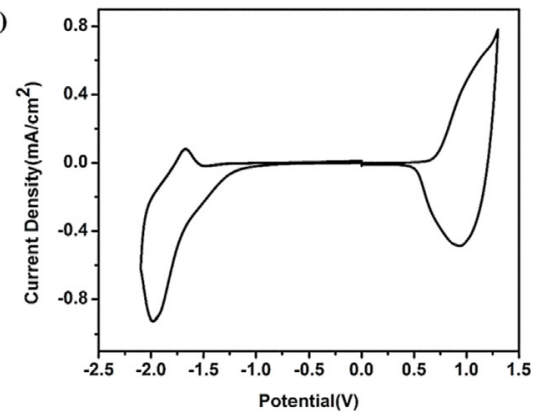

Fig. 1. Cyclic voltammograms of a) P1, b) P2, c) $\mathbf{P 3}$ and d) $\mathbf{P 4}$ in $0.1 \mathrm{M} \mathrm{TBAPF}_{6} / \mathrm{ACN}$ at $100 \mathrm{mV} / \mathrm{s}$ scan rate.

were determined using cyclic voltammetry studies. While HOMO and LUMO energy levels were calculated for P3 as $-5.45 /-3.25 \mathrm{eV}$, they were $-5.46 /-3.19 \mathrm{eV}$ for P4. According to these results, selenophene-based polymer $\mathbf{P 3}$ has lower band gap than thiophene-based polymer P4. Similar to previous studies, with the insertion of selenophene instead of thiophene resulting in decrease in LUMO level without changing the HOMO level [26-28]. The results of CV analyses were summarized in Table 1.

\subsection{Optical studies}

Optical properties of polymers were investigated in visible and NIR regions by spectrophotometer. Polymers were dissolved in $\mathrm{CHCl}_{3}$ and spray coated on ITO electrodes. As seen in Fig. 2, polymers have broad absorptions in visible region. Absorption spectra of P1 and P2 showed a peak at $575 \mathrm{~nm}$ with a shoulder at $615 \mathrm{~nm}$ for P1, $635 \mathrm{~nm}$ for P2. Shorter wavelength absorption can be assigned to $\pi-\pi^{*}$ transition, absorption at longer wavelengths can be assigned to intramolecular charge transfer (ICT) between the electron-rich and electron-deficient units [29]. The absorption spectra of the polymers were similar and this similarity between fluorinated and nonfluorinated polymers was previously reported in the literature [30,31].

While P3 showed a peak at $605 \mathrm{~nm}$ with a shoulder at $560 \mathrm{~nm}$, P4 showed a peak at $565 \mathrm{~nm}$ with a shoulder at $535 \mathrm{~nm}$. P3 has red shifted absorption spectrum compared to P4. Incorporation of electron rich selenophene moiety to the polymer backbone results in red shifted absorption profile.

As depicted in Fig. 2, all polymers showed broad absorption in visible region. There is no significant red-shift in thin film absorption compared to solution absorption for P1, P2 and P4, which proves the minority of the aggregation in thin film form [32,33].

Optical band gaps were determined from the $\lambda_{\max }^{\text {onst }}$ values which were $695 \mathrm{~nm}$ for P1, $720 \mathrm{~nm}$ for P2, $760 \mathrm{~nm}$ for P3 and $715 \mathrm{~nm}$ for P4. Optical band gaps for P1, P2, P3 and P4 are calculated as $1.78 \mathrm{eV}$, $1.72 \mathrm{eV}, 1.63 \mathrm{eV}$ and $1.73 \mathrm{eV}$, respectively. Results of optical studies

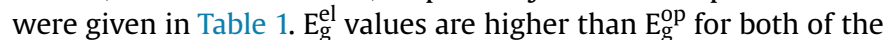
polymers due to the free electrons in the electrochemistry experiment [34].

\subsection{Spectroelectrochemistry studies}

In this experiment, polymer films were exposed to stepwise oxidation potential (Fig. 3). Polymers were dissolved in $\mathrm{CHCl}_{3}$ and spray coated on ITO coated glass substrates. $0.1 \mathrm{M} \mathrm{TBAPF}_{6} / \mathrm{ACN}$ were used as the supporting electrolyte/solvent system. Three electrode system which consists of reference electrode (Ag), counter electrode (Pt), and working electrode (polymer coated ITO) was immersed in supporting electrolyte/solvent. Upon applied potential, intensity of absorption of neutral state was depleting while formation of polaron bands around $800 \mathrm{~nm}$ were observed. Polymers have isosbestic points where interconversion of the

Table 1

Summary of electrochemical and optical properties of P1, P2, P3 and P4

\begin{tabular}{|c|c|c|c|c|c|c|c|c|c|c|}
\hline Polymer & $\mathrm{E}_{\mathrm{p} \text {-doping }}(\mathrm{V})$ & $\mathrm{E}_{\mathrm{n} \text {-doping }}(\mathrm{V})$ & $\mathrm{E}_{\mathrm{ox}}^{\text {onset }}(\mathrm{V})$ & $\mathrm{E}_{\mathrm{red}}^{\text {onset }}(\mathrm{V})$ & HOMO $(\mathrm{eV})$ & LUMO (eV) & $\mathrm{E}_{\mathrm{g}}^{\mathrm{el}}(\mathrm{eV})$ & $\lambda_{\max }(\mathrm{nm})$ & $\lambda_{\max }^{\text {onset }}(\mathrm{nm})$ & $\mathrm{E}_{\mathrm{g}}^{\mathrm{op}}(\mathrm{eV})$ \\
\hline P1 & 0.98 & - & 0.70 & - & -5.45 & $-3.67^{a}$ & - & 575 & 695 & 1.78 \\
\hline P2 & 1.07 & - & 0.80 & - & -5.55 & $-3.83^{\mathrm{a}}$ & - & 575 & 720 & 1.72 \\
\hline P3 & 1.05 & -1.90 & 0.70 & -1.50 & -5.45 & -3.25 & 2.20 & 605 & 760 & 1.63 \\
\hline P4 & 1.18 & -1.98 & 0.71 & -1.56 & -5.46 & -3.19 & 2.27 & 565 & 715 & 1.73 \\
\hline
\end{tabular}

a This value was calculated from the formula $\mathrm{LUMO}=\mathrm{HOMO}+\mathrm{E}_{\mathrm{g}}^{\mathrm{op}}$. 
a)
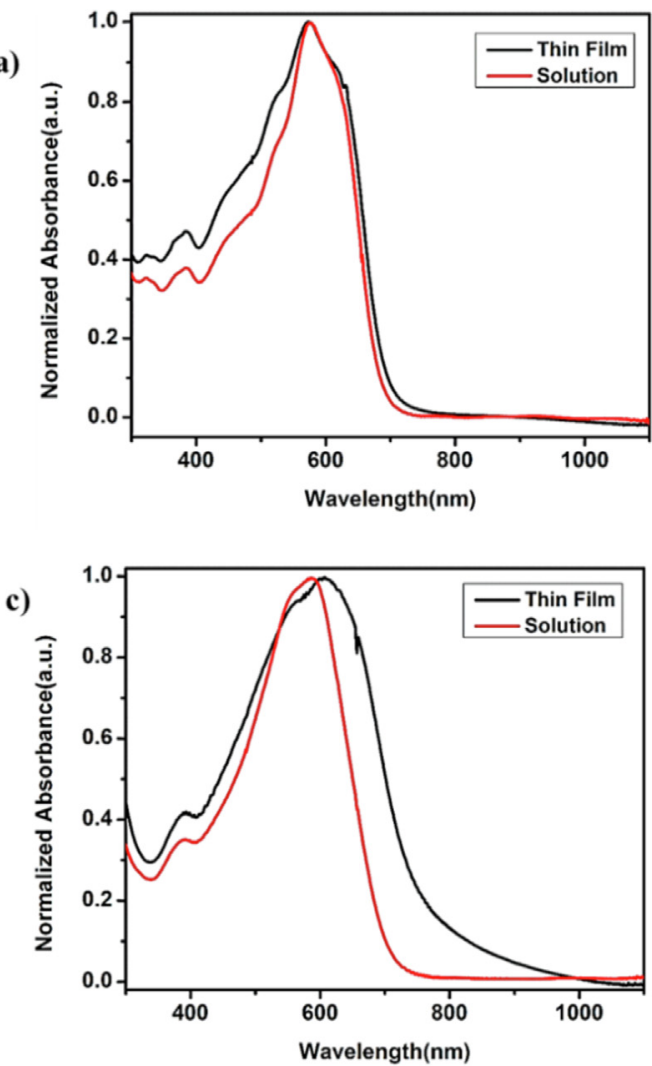

b)

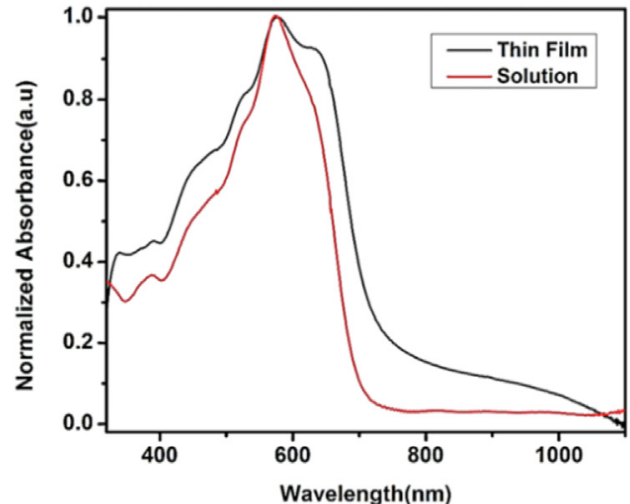

d)

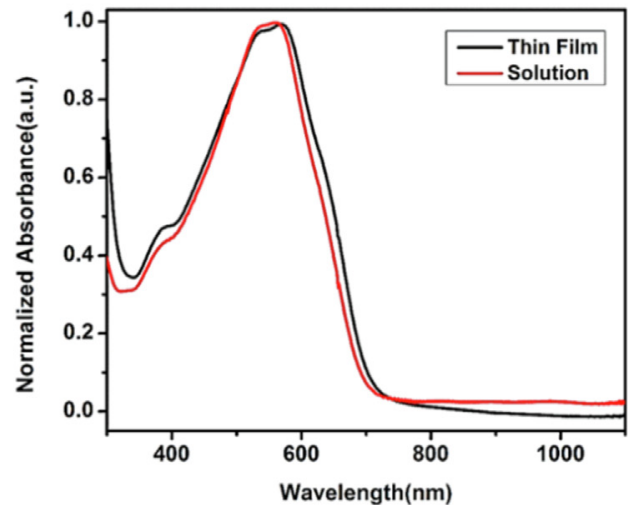

Fig. 2. UV-Vis normalized absorption spectra in $\mathrm{CHCl}_{3}$ solution and film for a) P1, b) P2, c) P3, d) P4
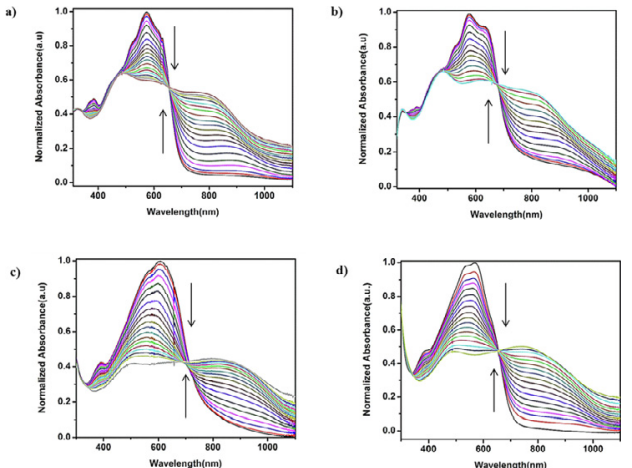

Fig. 3. Electronic normalized absorption spectra of polymer films recorded at various potentials for a) P1, b) P2, c) $\mathbf{P 3}$ and d) $\mathbf{P 4}$ in $0.1 \mathrm{M} \mathrm{TBAPF}_{6} / \mathrm{ACN}$ solution.

polymers from their neutral states to the oxidized states takes place [35] at $656 \mathrm{~nm}$ for P1, $678 \mathrm{~nm}$ for P2, $710 \mathrm{~nm}$ for P3 and $655 \mathrm{~nm}$ for P4, respectively.

\subsection{Kinetic studies}

In order to investigate optical contrast and switching time of the polymers kinetic studies were carried out. Optical contrast is the percent transmittance change between the neutral and fully oxidized states of a material at a given wavelength. The time required for switching between these states is defined as the switching time. In the literature, switching time is calculated from $95 \%$ of the full contrast since human eye is insensitive to $5 \%$ of color change [36]. Three electrode system was constructed in a quartz cell as described for the spectroelectrochemistry part. Then, absorption spectrum was recorded by applying square-wave potential between neutral and fully oxidized states with $5 \mathrm{~s}$ time internals (Fig. 4). This measurement was repeated for the wavelengths where polymers showed maximum absorption.

Table 2 summarizes the kinetic parameters of the polymers. Optical contrast of the polymers in the visible region are close to each other. As depicted in Table 2, incorporation of selenophene and thiophene $\pi$ bridges improved switching time. In the NIR region, the highest optical contrast was observed in P1 with 59\%.

\subsection{Thermal studies}

Differential scanning calorimetry (DSC) was used to determine thermal transitions. Polymers did not show any phase transition and significant degradation up to $300^{\circ} \mathrm{C}$. Thermal stability of the polymers was investigated with thermogravimetry analyses (TGA). These analyses showed that decomposition temperatures of P1, P2, P3 and P4 were at $327^{\circ} \mathrm{C}, 322^{\circ} \mathrm{C}, 331^{\circ} \mathrm{C}$ and $326^{\circ} \mathrm{C}$, respectively.

\subsection{Photovoltaic studies}

Polymer solar cells were constructed using P1, P2, P3 and P4 as the electron donors with the conventional device architecture; ITO/ PEDOT:PSS/Polymer:PC ${ }_{71} \mathrm{BM} / \mathrm{LiF} / \mathrm{Al}$. Several optimizations were performed, including the Polymer: $\mathrm{PC}_{71} \mathrm{BM}$ blend ratio $(\mathrm{w} / \mathrm{w})$, blend concentration and addition of DIO (1,8-diiodooctane). These results are summarized in Table 3 and corresponding $J-\mathrm{V}$ curves are depicted in Fig. 5 a) and b). In addition to DIO addition, effect of chloronaphthalene as an additive, thermal annealing and methanol treatment were also examined, however there have been no enhancement for the photovoltaic performance of the polymers.

For $\mathbf{P 1}$ based PSCs, polymer $\mathrm{PC}_{71} \mathrm{BM}$ ratio altered from $1: 1$ to $1: 4$. 
a)
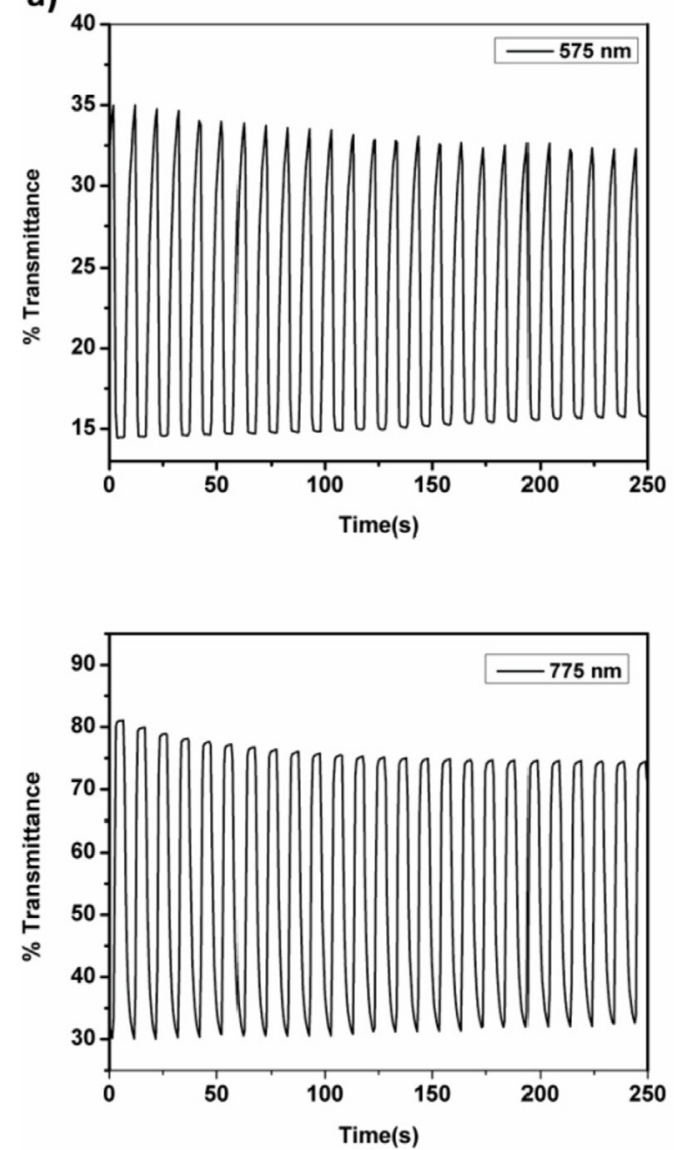

c)
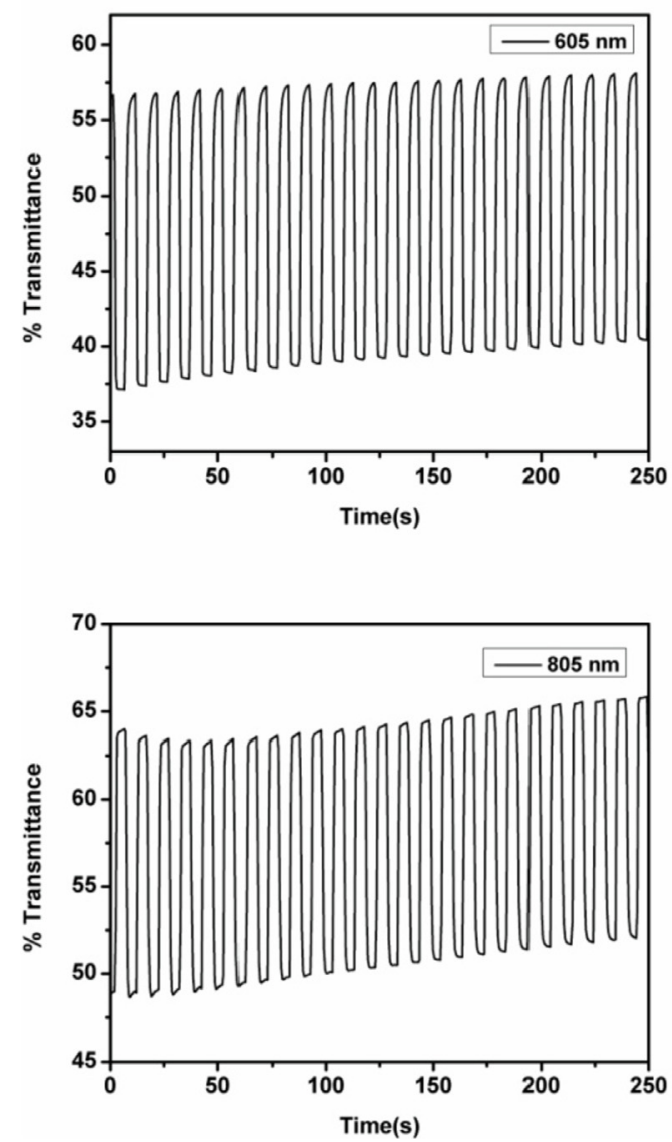

b)
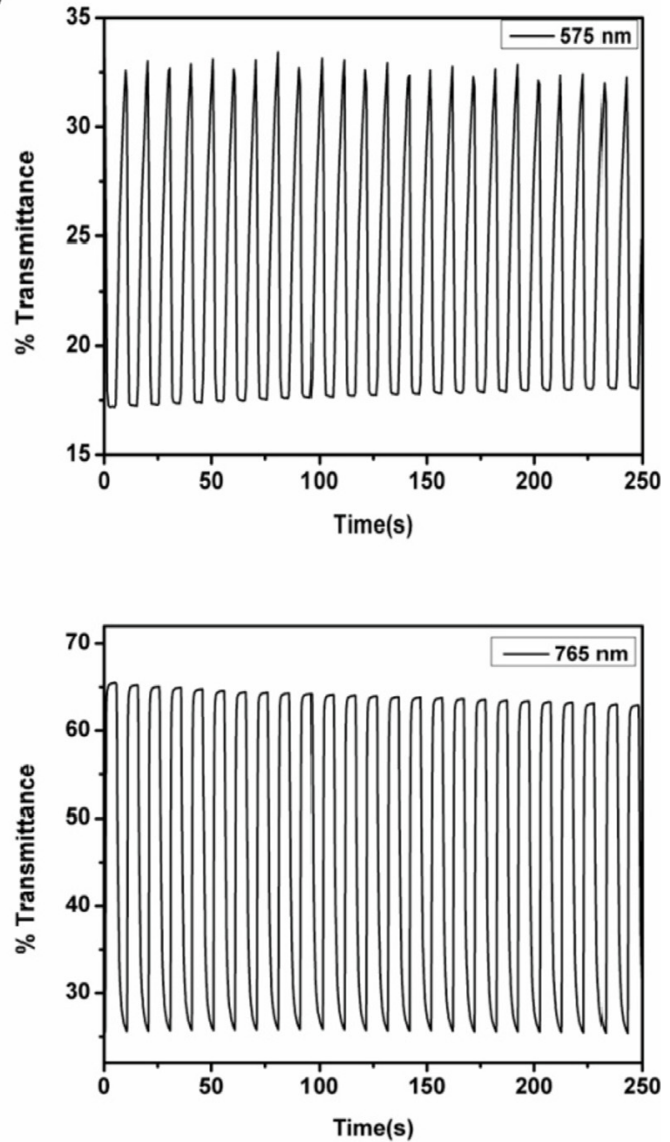

d)
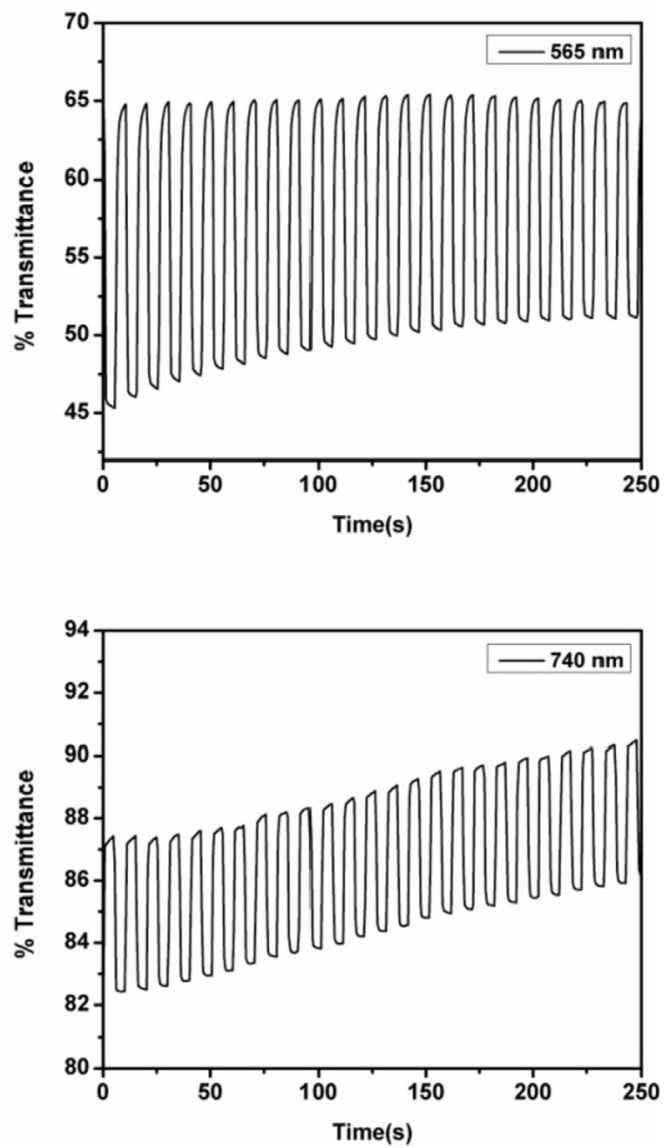

Fig. 4. Percent transmittance changes of a) $\mathbf{P 1}$, b) $\mathbf{P 2}$, c) $\mathbf{P} 3$ and d) $\mathbf{P 4}$ in $0.1 \mathrm{M} \mathrm{TBAPF}_{6} / \mathrm{ACN}$ solution. 
Table 2

Summary of kinetic studies of the polymers.

\begin{tabular}{llll}
\hline Polymer & Wavelength $(\mathrm{nm})$ & Optical Contrast $(\Delta \mathrm{T} \%)$ & Switching Time $(\mathrm{s})$ \\
\hline P1 & 575 & 24 & 3.6 \\
& 775 & 59 & 1.5 \\
P2 & 575 & 17 & 4.2 \\
& 765 & 42 & 0.6 \\
P3 & 605 & 21 & 1.7 \\
& 805 & 19 & 1.1 \\
P4 & 565 & 23 & 2.2 \\
& 740 & 7 & 0.8 \\
\hline
\end{tabular}

Table 3

Summary of the photovoltaic properties, where ${ }^{\mathrm{a}}$ is for $2 \%$ DIO addition, ${ }^{\mathrm{b}}$ is for $3 \%$ DIO addition, and ${ }^{\mathrm{c}}$ is for $4 \%$ DIO addition.

\begin{tabular}{llllll}
\hline Polymer:PC ${ }_{71} \mathrm{BM}$ & \% (concentration) & $\mathrm{V}_{\mathrm{OC}}(\mathrm{V})$ & $\mathrm{J}_{\mathrm{SC}}\left(\mathrm{mA} \mathrm{cm}^{-2}\right)$ & $\mathrm{FF}(\%)$ & $\mathrm{PCE}(\%)$ \\
\hline P1 $(1: 2)$ & 2 & 0.77 & 6.19 & 39.0 & 1.86 \\
P1 $(1: 3)$ & 2 & 0.78 & 5.67 & 54.5 & 2.41 \\
P1 $(1: 3)$ & 3 & 0.76 & 4.83 & 38.7 & 1.42 \\
P1 $(1: 3)^{\mathrm{a}}$ & 2 & 0.77 & 9.51 & 56.0 & 4.10 \\
P2 $(1: 2)$ & 2 & 0.76 & 9.00 & 56.1 & 3.84 \\
P2 $(1: 3)$ & 2 & 0.78 & 7.43 & 55.8 & 3.23 \\
P2 $(1: 2)$ & 3 & 0.78 & 8.41 & 49.2 & 3.23 \\
P2 $(1: 2)^{\mathrm{b}}$ & 2 & 0.77 & 7.13 & 50.8 & 2.79 \\
P3 $(1: 2)$ & 2 & 0.66 & 4.24 & 51.6 & 1.44 \\
P3 $(1: 3)$ & 2 & 0.64 & 3.80 & 65.6 & 1.60 \\
P3 $(1: 3)^{\mathrm{a}}$ & 2 & 0.57 & 4.14 & 59.5 & 1.40 \\
P4 $(1: 2)$ & 2 & 0.75 & 3.44 & 38.6 & 1.00 \\
P4 $(1: 3)$ & 2 & 0.71 & 4.39 & 56.2 & 1.75 \\
P4 $(1: 3)$ & 3 & 0.76 & 5.99 & 64.1 & 2.92 \\
P4 $(1: 3)^{\mathrm{c}}$ & 3 & 0.66 & 8.84 & 65.6 & 3.83 \\
\hline
\end{tabular}

Polymer $\mathrm{PC}_{71} \mathrm{BM} 1: 3 \mathrm{wt}$ ratio with an active layer thickness of $124 \mathrm{~nm}$, exhibited the best performance. When polymer $\mathrm{PC}_{71} \mathrm{BM}$ ratio altered from $1: 2$ to $1: 3$, $J_{S C}$ value was decreased from $6.19 \mathrm{mAcm}^{-2}$ to $5.67 \mathrm{mAcm}^{-2}$ with the increased $\mathrm{PC}_{71} \mathrm{BM}$ loading. However, PCE value was improved through a rise in FF values. Lower $J_{S C}$ values can be correlated to blend's reduced ability to harvest the irradiated light, due to increased content of $\mathrm{PC}_{71} \mathrm{BM}$ [37]. Enhancement of PCE is due to a rise in FF which may be attributed to the improved morphology of the active layer [38]. With the addition of $3 \% \mathrm{v} / \mathrm{v}$ DIO, PCE value was improved to $4.10 \%$ with a $\mathrm{V}_{\mathrm{OC}}$ value of $0.77 \mathrm{~V}$, a $J_{\mathrm{SC}}$ value of $9.51 \mathrm{mAcm}^{-2}$ and a $\mathrm{FF}$ of 56.0\%. Corresponding J-V curve is shown in Fig. 5b). For P2 based PSCs, the best performance was obtained from a blend of P2: $\mathrm{PC}_{71} \mathrm{BM}$ in 1:2 wt ratio resulting in $105 \mathrm{~nm}$ active layer thickness, afforded a PCE of $3.84 \%$, with a JSC of $9.00 \mathrm{mAcm}^{-2}$, a $\mathrm{V}_{\mathrm{OC}}$ of $0.76 \mathrm{~V}$ and a (FF) of $56.1 \%$ without any treatment. Characterization for $\mathbf{P} 3$ based PSCs in terms of polymer- $\mathrm{PC}_{71} \mathrm{BM}$ ratio has shown that the best performance was obtained for the blend ratio of $1: 3$, with $72 \mathrm{~nm}$ thick active layer, with a PCE value of $1.60 \%$. The P4:PC ${ }_{71} \mathrm{BM}$ (1:3) device ( $2 \mathrm{wt} \%$ concentration) processed from o-dcb showed a $J_{\mathrm{SC}}$ of $4.39 \mathrm{mAcm}^{-2}, \mathrm{~V}_{\mathrm{OC}}$ of $0.71 \mathrm{~V}$, and an FF of $56.2 \%$, yielding a PCE of $1.75 \%$. Increase in blend concentration from $2 \%$ to $3 \%$ yields to a thicker active layer and a rise in PCE significantly to $2.92 \%$. Similar to previous publications, increasing active layer thickness results in $J_{S C}$ raise $[39,40]$. This is mainly due to the active layer's enhanced capacity of harvesting sun light. With $4 \%$ DIO addition, performance of P4 based PSC is enhanced and attains a PCE of 3.83\% through a rise in JsC and FF values. Among the polymers, P1 showed superior performance. For the $\mathbf{P 2}$ based PSCs which are based on fluorinated derivative of P1, higher $\mathrm{V}_{\mathrm{OC}}$ values were expected due to the presence of electronegative fluorine atom, with a deep lying HOMO. However, $V_{O C}$ values obtained for both polymers are approximately the same, around $0.77 \mathrm{~V}$ due to very close HOMO
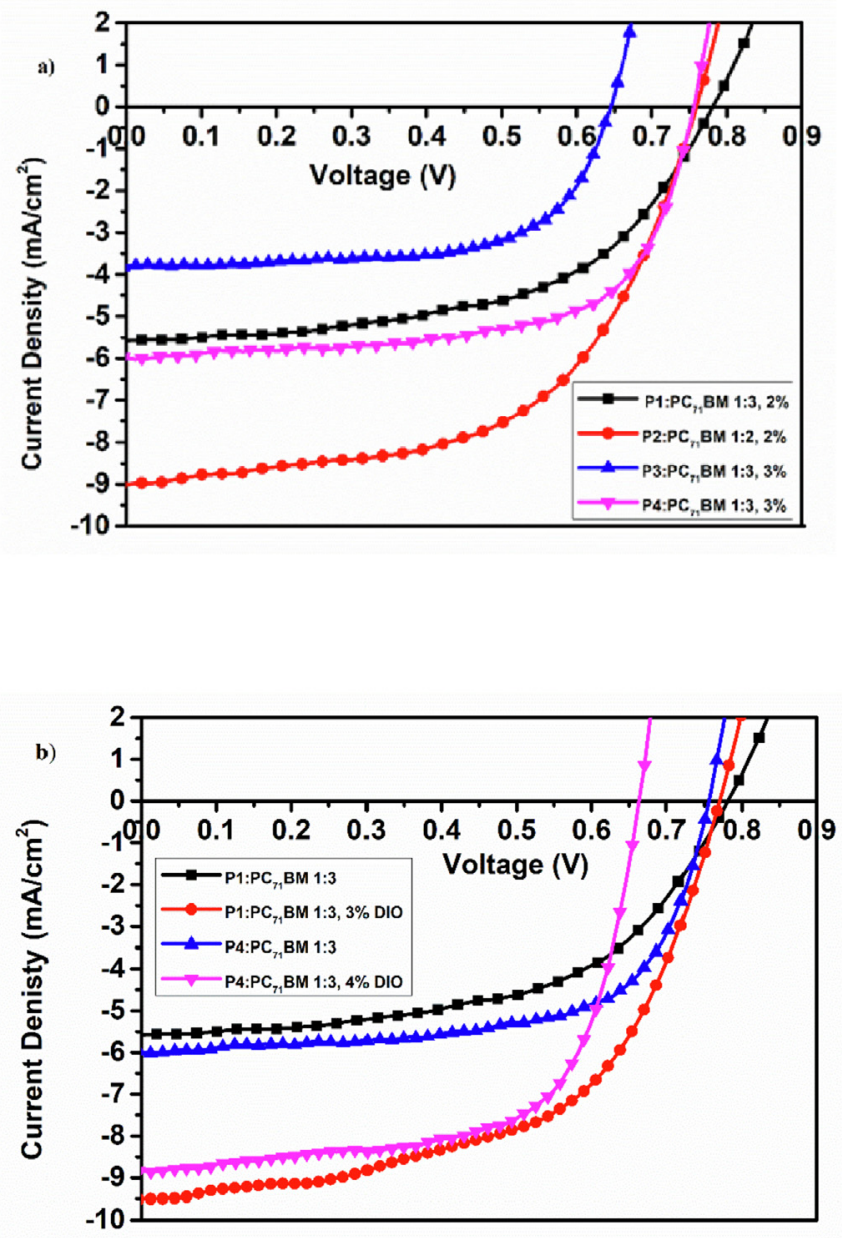

Fig. 5. J-V curves of PSCs based on a) best performance PSCs based on P1, P2, P3 and P4 without additive treatment b) best performance PSCs based on P1 and P4 with and without additive treatment.

energy levels of P1 and P2.

To gain more insight into the active layer morphologies, TEM analyses were carried out. TEM images of active layers are shown in
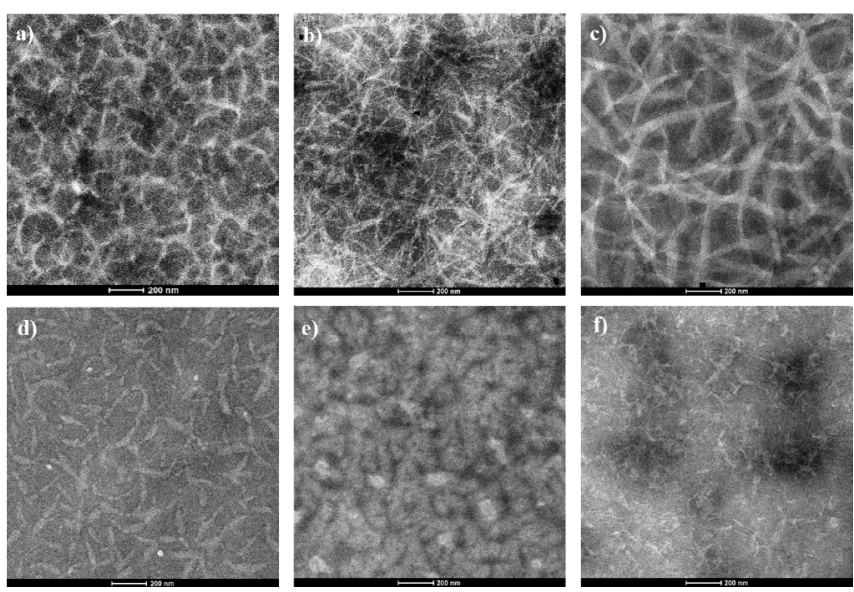

Fig. 6. TEM images of a) $\mathbf{P 1}: \mathrm{PC}_{71} \mathrm{BM}$ processed from 0 -dcb b) $\mathbf{P 1}: \mathrm{PC}_{71} \mathrm{BM}$ processed from 0 -dcb with $3 \% \mathrm{DIO}$ c) P2: $\mathrm{PC}_{71} \mathrm{BM}$ processed from 0 -dcb d) P3: $\mathrm{PC}_{71} \mathrm{BM}$ processed from 0 -dcb e) $\mathbf{P 4}: \mathrm{PC}_{71} \mathrm{BM}$ processed from 0 -dcb f) $\mathbf{P 4}: \mathrm{PC}_{71} \mathrm{BM}$ processed from 0 -dcb with $4 \%$ DIO. 
Fig. 6. P3 and P4 are low molecular weight polymers thus have better solubility which leads to the formation of wider fibrils [41], as seen in Fig. 6d) and e). Morphology of the P4:PC ${ }_{71} B M$ layer (Fig. 6e) was improved with the addition of DIO (Fig. 6f). As depicted in Fig. 6b) and f), with the addition of DIO to the P1:PC ${ }_{71} \mathrm{BM}$ (Fig. 6a) and P4:PC ${ }_{71} \mathrm{BM}$ (Fig. 6e) blend, narrower fibrillary structures, where excitons are more likely to reach donor acceptor interface, were formed [41]. Lower photovoltaic performance of $\mathbf{P 3}$ based PSCs may be due to the wide fibrils observed in Fig. 6d).

\section{Conclusions}

A novel D-A type conjugated polymer P1 that is comprising BTD and BDT units and its derivatives were successfully synthesized. Fluorinated derivative was denoted as $\mathbf{P 2}$, and the selenophene and thiophene containing derivatives of P2 were denoted as P3 and P4 respectively. Electrochemical, optical, spectroelectrochemical, kinetic, thermal and photovoltaic studies were carried out for each polymer. Thermal studies approved that the polymers are thermally stable up to $300^{\circ} \mathrm{C}$. Electrochemical studies showed that $\mathbf{P 3}$ and $\mathbf{P 4}$ possess ambipolar character, while $\mathbf{P 1}$ and $\mathbf{P 2}$ are only pdopable. HOMO levels of P1 and P2 were determined as $-5.45 \mathrm{eV}$ and $-5.55 \mathrm{eV}$ respectively, while for $\mathbf{P} \mathbf{3}$ and $\mathbf{P 4}$, the frontier orbital energy levels were calculated as $-5.45 /-3.25 \mathrm{eV}$, and $-5.46 /-$ $3.19 \mathrm{eV}$ respectively. $\mathrm{E}_{\mathrm{g}}^{\mathrm{op}}$ values were calculated as $1.78 \mathrm{eV}$ for P1, $1.72 \mathrm{eV}$ for P2, $1.63 \mathrm{eV}$ for $\mathbf{P 3}$ and $1.73 \mathrm{eV}$ for P4. Highest PCE values were recorded as 4.10\% 3.84\%, 1.60\% and 3.83\% for P1, P2, P3 and P4 based PSCs, respectively.

Among the polymers, P1 based PSCs exhibited the highest photovoltaic performance with a $\mathrm{V}_{\mathrm{OC}}$ of $0.77 \mathrm{~V}$, a $J_{S C}$ of $9.51 \mathrm{mAcm}^{-2}$ and an FF of $56.0 \%$ and attains a PCE of $4.10 \%$.

\section{Acknowledgments}

This study supported by the Scientific and Technological Research Council of Turkey (TUBITAK) (Project number: 115M036). We express our sincere thanks for their financial support.

\section{References}

[1] D.K. Gupta, M. Langelaar, M. Barink, F. Van Keulen, Optimizing front metallization patterns: efficiency with aesthetics in free-form solar cells, Renew. Energy 86 (2016) 1332-1339, https://doi.org/10.1016/j.renene.2015.09.071.

[2] H. Hoppe, N.S. Sariciftci, Organic solar cells: an overview, J. Mater. Res. 19 (2004) 1924-1945, https://doi.org/10.1557/JMR.2004.0252.

[3] W. Li, B. Guo, C. Chang, X. Guo, M. Zhang, Y. Li, Efficient polymer solar cells based on a copolymer of: meta -alkoxy-phenyl-substituted benzodithiophene and thieno[3,4-b] thiophene, J. Mater. Chem. A. 4 (2016) 10135-10141, https://doi.org/10.1039/c6ta04030f.

[4] L. Meng, Y. Zhang, X. Wan, C. Li, X. Zhang, Y. Wang, X. Ke, Z. Xiao, L. Ding, R. Xia, H.-L. Yip, Y. Cao, Y. Chen, Organic and solution-processed tandem solar cells with $17.3 \%$ efficiency, Science 1098 (2018) 1094-1098, https://doi.org/ $10.1126 /$ science.aat2612.

[5] E. Palomares, Benzothiadiazole substituted semiconductor molecules for organic solar cells: the effect of the solvent annealing over the thin film hole mobility values, J. Phys. Chem. C 122 (2018) 13782-13789, https://doi.org/ 10.1021/acs.jpcc.8b00840.

[6] Z. Yi, W. Ni, O. Zhang, M. Li, B. Kan, X. Wan, Y. Chen, Effect of thermal annealing on active layer morphology and performance for small molecule bulk heterojunction organic solar cells, J. Mater. Chem. C 2 (2014) 7247-7255, https://doi.org/10.1039/c4tc00994k.

[7] H.C. Liao, C.C. Ho, C.Y. Chang, M.H. Jao, S.B. Darling, W.F. Su, Additives for morphology control in high-efficiency organic solar cells, Mater. Today 16 (2013) 326-336, https://doi.org/10.1016/j.mattod.2013.08.013.

[8] A. Laventure, G.C. Welch, A tetrachlorinated molecular non-fullerene acceptor for high performance near-IR absorbing organic solar cells, J. Mater. Chem. C 6 (2018) 9060-9064, https://doi.org/10.1039/c8tc02701c.

[9] G. Oklem, X. Song, L. Toppare, D. Baran, G. Gunbas, A new NIR absorbing DPPbased polymer for thick organic solar cells, J. Mater. Chem. C. 6 (2018) 2891-3106, https://doi.org/10.1039/c8tc00113h.

[10] X. Gong, G. Li, C. Li, J. Zhang, Z. Bo, Benzothiadiazole based conjugated polymers for high performance polymer solar cells, J. Mater. Chem. A 3 (2015) 20195-20200, https://doi.org/10.1039/c5ta06065f.

[11] M.-F.F. Falzon, M.M. Wienk, R. a. J. Janssen, Designing acceptor polymers for organic photovoltaic devices, J. Phys. Chem. C 115 (2011) 3178-3187, https:// doi.org/10.1021/jp110990w.

[12] M. Karakus, D.H. Apaydin, D.E. Yldz, L. Toppare, A. Cirpan, Benzotriazole and benzothiadiazole containing conjugated copolymers for organic solar cell applications, Polymer 53 (2012) 1198-1202, https://doi.org/10.1016 j.polymer.2012.01.030.

[13] D. Kotowski, S. Luzzati, G. Bianchi, A. Calabrese, A. Pellegrino, R. Po, G. Schimperna, A. Tacca, Double acceptor D-A copolymers containing benzotriazole and benzothiadiazole units: chemical tailoring towards efficient photovoltaic properties, J. Mater. Chem. A. 1 (2013) 10736-10744, https:// doi.org/10.1039/c3ta11698k.

[14] H. Chen, J. Hou, S. Zhang, Y. Liang, G. Yang, Y. Yang, Polymer solar cells with enhanced open-circuit voltage and efficiency, Nat. Photon. 3 (2009) 649-653, https://doi.org/10.1038/NPHOTON.2009.192.

[15] H.J. Son, W. Wang, T. Xu, Y. Liang, Y. Wu, G. Li, L. Yu, Synthesis of fluorinated polythienothiophene- co -benzodithiophenes and effect of fluorination on the photovoltaic properties, J. Am. Chem. Soc. 133 (2011) 1885-1894, https:/ doi.org/10.1039/C6PY00346J.

[16] H. Zhou, L. Yang, A.C. Stuart, S.C. Price, S. Liu, W. You, Development of fluorinated benzothiadiazole as a structural unit for a polymer solar cell of $7 \%$ efficiency, Angew. Chem. Int. Ed. 50 (2011) 2995-2998, https://doi.org/ 10.1002/anie.201005451.

17] A.C. Stuart, J.R. Tumbleston, H. Zhou, W. Li, S. Liu, H. Ade, Fluorine substituents reduce charge recombination and drive structure and morphology development in polymer solar cells, J. Am. Chem. Soc. 135 (2013) 1806-1815, https:// doi.org/10.1021/ja309289u.

[18] A.A.B. Alghamdi, D.C. Watters, H. Yi, S. Al-Faifi, M.S. Almeataq, D. Coles, J. Kingsley, D.G. Lidzey, A. Iraqi, Selenophene vs. thiophene in benzothiadiazole-based low energy gap donor-acceptor polymers for photovoltaic applications, J. Mater. Chem. A. 1 (2013) 5165-5171, https:// doi.org/10.1039/c3ta00122a.

[19] M. Shahid, T. McCarthy-Ward, J. Labram, S. Rossbauer, E.B. Domingo, S.E. Watkins, N. Stingelin, T.D. Anthopoulos, M. Heeney, Low band gap selenophene-diketopyrrolopyrrolepolymers exhibiting high and balanced ambipolar performance in bottom-gate transistors, Chem. Sci. 3 (2012) 181-185, https://doi.org/10.1039/C1SC00477H.

[20] J.J. Intemann, K. Yao, H.L. Yip, Y.X. Xu, Y.X. Li, P.W. Liang, F.Z. Ding, X. Li, A.K.Y. Jen, Molecular weight effect on the absorption, charge carrier mobility, and photovoltaic performance of an indacenodiselenophene-based laddertype polymer, Chem. Mater. 25 (2013) 3188-3195, https://doi.org/10.1021 cm401586t.

[21] I. Onk, G. Hizalan, S.C. Cevher, S.O. Hacioglu, L. Toppare, A. Cirpan, Multipurpose selenophene containing conjugated polymers for optoelectronic applications, J. Macromol. Sci. Part A Pure Appl. Chem. 54 (2017) 133-139, https:/ doi.org/10.1080/10601325.2017.1265396.

[22] O. Erlik, N.A. Unlu, G. Hizalan, S.O. Hacioglu, S. Comez, E.D. Yildiz, L. Toppare, A. Cirpan, Silafluorene-based polymers for electrochromic and polymer sola cell applications, J. Polym. Sci., Part A: Polym. Chem 53 (2015) 1541-1547, https://doi.org/10.1002/pola.27625.

[23] J. Kim, M.H. Yun, G.H. Kim, J. Lee, S.M. Lee, S.J. Ko, Y. Kim, G.K. Dutta, M. Moon, S.Y. Park, D.S. Kim, J.Y. Kim, C. Yang, Synthesis of PCDTBT-based fluorinated polymers for high open-circuit voltage in organic photovoltaics: towards an understanding of relationships between polymer energy levels engineering and ideal morphology control, ACS Appl. Mater. Interfaces 6 (2014) 7523-7534, https://doi.org/10.1021/am500891z.

[24] Z. Fei, M. Shahid, N. Yaacobi-Gross, S. Rossbauer, H. Zhong, S.E. Watkins, T.D. Anthopoulos, M. Heeney, Thiophene fluorination to enhance photovoltaic performance in low band gap donor-acceptor polymers, Chem. Commun. 48 (2012) 11130-11132, https://doi.org/10.1039/c2cc35079c.

[25] P. Liu, K. Zhang, F. Liu, Y. Jin, S. Liu, T.P. Russell, H.-L. Yip, F. Huang, Y. Cao Effect of fluorine content in thienothiophene-benzodithiophene copolymers on the morphology and performance of polymer solar cells, Chem. Mater. 26 (2014) 3009-3017, https://doi.org/10.1021/cm500953e.

[26] A. Patra, M. Bendikow, Polyselenophenes, J. Mater. Chem. 20 (2010) 422-433, https://doi.org/10.1039/b908983g.

[27] H.-Y. Chen, S.-C. Yeh, C.-T. Chen, C.-T. Chen, Comparison of thiophene- and selenophene-bridged donor-acceptor low bandgap copolymers used in bulkheterojunction organic photovoltaics, J. Mater. Chem. 22 (2012) 21549-21559, https://doi.org/10.1039/c2jm33735e.

[28] B. Kim, H.R. Yeom, M.H. Yun, J.Y. Kim, C. Yang, A selenophene analogue of PCDTBT: selective fine-tuning of LUMO to lower of the bandgap for efficient polymer solar cells, Macromolecules 45 (2012) 8658-8664, https://doi.org/ 10.1021/ma302133h.

[29] M. Yuan, P. Yang, M.M. Durban, C.K. Luscombe, Low bandgap polymers based on silafluorene containing multifused heptacyclic arenes for photovoltaic applications, Macromolecules 45 (2012) 5934-5940, https://doi.org/10.1021/ ma300839c.

[30] P. Yang, M. Yuan, D.F. Zeigler, S.E. Watkins, J.A. Lee, C.K. Luscombe, Influence of fluorine substituents on the film dielectric constant and open-circuit voltage in organic photovoltaics, J. Mater. Chem. C. 2 (2014) 3278-3284, https:/ doi.org/10.1039/C3TC32087A.

[31] S.C. Price, A.C. Stuart, L. Yang, H. Zhou, W. You, Fluorine substituted 
conjugated polymer of medium band gap yields $7 \%$ efficiency in polymerfullerene solar cells, J. Am. Chem. Soc. 133 (2011) 4625-4631, https:// doi.org/10.1021/ja1112595.

[32] T.-Q. Nguyen, I.B. Martini, J. Liu, B.J. Schwartz, Controlling interchain in teractions in conjugated polymers: the effects of chain morphology on exciton-exciton annihilation and aggregation in MEH-PPV films, J. Phys. Chem. B 104 (2000) 237-255, https://doi.org/10.1021/jp993190c.

[33] G. Hizalan, A. Balan, D. Baran, L. Toppare, Spray processable ambipolar benzotriazole bearing electrochromic polymers with multi-colored and transmissive states, J. Mater. Chem. 21 (2011) 1804-1809, https://doi.org/10.1039/ COJM03000G

[34] S.W. Cho, L.F.J. Piper, A. Demasi, A.R.H. Preston, K.E. Smith, K.V. Chauhan, P. Sullivan, R.A. Hatton, T.S. Jones, Electronic structure of C60/phthalocyanine/ ITO interfaces studied using soft X-ray spectroscopies, J. Phys. Chem. C 114 (2010) 1928-1933, https://doi.org/10.1021/jp910504a.

[35] M. Akbayrak, A.M. Önal, Synthesis and electrochemical polymerization of diketopyrrolopyrrole based donor-acceptor-donor monomers containing 3,6- and 2,7-linked carbazoles, Polym. Chem. 7 (2016) 6110-6119, https:// doi.org/10.1039/C6PY01489E.

[36] N.A. Unlu, T.K. Deniz, M. Sendur, A. Cirpan, Effect of dithienopyrrole unit on electrochromic and optical properties of benzotriazole-based conjugated polymers, Macromol. Chem. Phys. 213 (2012) 1885-1891, https://doi.org/ 10.1002/macp.201200274.

[37] T. Kietzke, R.Y.C. Shin, D.A.M. Egbe, Z.K. Chen, A. Sellinger, Effect of annealing on the characteristics of organic solar cells: polymer blends with a 2-vinyl4,5-dicyanoimidazole derivative, Macromolecules 40 (2007) 4424-4428, https://doi.org/10.1021/ma0706273.

[38] X. Liu, C. Zhang, C. Duan, M. Li, Z. Hu, J. Wang, F. Liu, N. Li, C.J. Brabec, R.A.J. Janssen, G.C. Bazan, F. Huang, Y. Cao, Morphology optimization via side chain engineering enables all-polymer solar cells with excellent fill factor and stability, J. Am. Chem. Soc. 140 (2018) 8934-8943, https://doi.org/10.1021/ jacs.8b05038.

[39] W. Li, K.H. Hendriks, W.S.C. Roelofs, Y. Kim, M.M. Wienk, R.A.J. Janssen, Efficient small bandgap polymer solar cells with high fill factors for $300 \mathrm{~nm}$ thick films, Adv. Mater. 25 (2013) 3182-3186, https://doi.org/10.1002/ adma.201300017.

[40] V. Vohra, K. Kawashima, T. Kakara, T. Koganezawa, I. Osaka, K. Takimiya, $\mathrm{H}$. Murata, Efficient inverted polymer solar cells employing favourable molecular orientation, Nat. Photon. 9 (2015) 403-408, https://doi.org/10.1038/ nphoton.2015.84.

[41] W. Li, K.H. Hendriks, A. Furlan, W.S.C. Roelofs, S.C.J. Meskers, M.M. Wienk, R.A.J. Janssen, Effect of the fibrillar microstructure on the efficiency of high molecular weight diketopyrrolopyrrole-based polymer solar cells, Adv. Mater. 26 (2014) 1565-1570, https://doi.org/10.1002/adma.201304360. 